\title{
Students' Perception Of Using Social NETWORKING WEBSITES FOR EDUCATIONAL Purposes: Comparison BETwEen Two ARAB UNIVERSITIES
}

\author{
Heba Mohammad and Hatem Tamimi \\ Higher College of Technology, Computer Information Science Division, Abu Dhabi, \\ UAE
}

\begin{abstract}
Higher education institutions are adopting innovative solutions and tools to enhance their educational outcomes and attract more learners. Social network websites (SNSs) are example about such technologies, which attracted the attention of instructors as well as students. This research aims to understand the students' perceptions regarding using Social networking websites within their learning process. Also, to understand if student gender and nationality has influence on using SNSs. Data had been collected using an electronic questionnaire distributed among undergraduate students of two well-known universities'; Imam Mohammad Ibn Saud Islamic University which is located in Riyadh-Saudi Arabia and the second one is University of Jordan which is located in Amman-Jordan. Statistical analysis had been applied to the collected data. The results shows difference between students answers when it's been compared on country basis.
\end{abstract}

\section{KEYWORDS}

Social Networking Websites (SNs), Higher Education, Social Learning, Collaborative Learning.

\section{INTRODUCTION}

The rapid development in technologies forces organizations to adopt different solutions in order to sustain their market position and improve their performance. This had been manifested in higher education institutions by adopting innovative solutions and tools to enhance their educational outcomes and attract more learners. Universities and educational institutions are seeking to provide new methods and tools for interaction $[4,25]$. Social networking websites (SNSs) are example about such technologies which attracted the attention of instructors as well as students.

Students are using these websites to connect and interact with friends and others. Also, they use it to share knowledge, look for information and try to solve problems related to their learning activities. Thus, students are aggressively adopting social networking sites to perform different activities and tasks in order to enhance their learning.

Embedding new technologies within the learning process needs to be wisely introduced and carefully designed. Such field encourages a lot of research, where many scholars research is discussed. For using social networking websites as an educational tool and integrated within the learning process [21, 4], still more investigation needs to be done in order to clarify their value as 
a learning environment [16]. Consequently, this paper aims to understand the students' perceptions regarding using Social networking websites within their learning process.

\section{SOCIAL LEARNING THEORY}

The social learning theory discusses that individuals learn from their social interactions within their social systems [5]. Based on [8] argument, individuals have the ability to learn not just from their own experiences but also from others experiences. Literature explained that we are focusing during our learning to symbolic, live concepts that exist in our environment. Also, we learn by recalling different concepts that we had exposed to during our life. Then, we as learners' have the ability to reproduce what we retain and recall. Bandura explanation of social learning of individuals went through four components as described before; attentional processes, retention processes, motor reproduction processes, and motivational processes [8]. Also, he argued that people learn through observation and learning happened as result of the interaction between learner behavior, personal factors and environment. This is what he named as observational learning theory.

Another contribution to social learning theory is based on Wenger work [28]. He argues that individuals learn from their own life experience through interaction and participation in the world. His contribution of social learning theory highlighted that learning is constructed based on social nature of individuals, individual ability and competences enable them to own and construct knowledge. Also, he stressed that knowing is associated with learners engagement and mutual participation in social interactions with other learners. Furthermore, individuals ability to produce a meaningful outcome from their interactions is a result of their own understanding and meaningful experience in the world. Based on Wenger explanation for social learning, he suggested four key elements that contributed to our learning. Wenger [28] believes that learning is a matter of social interactions, participation and engagement with learners' context and where they belong. Leaners beliefs and perceptions of what they have gain from their social participation and practice will manifest in their actions and outcomes which will define who we are. Those four elements are identity, practice, meaningful, and community. Identity defines who we are and how we will interact and participate in our community. Practice defines how we will learn as a consequence of our actions. Meaningful explanation is how we will interpret and explain our actions. Community is related to where we belong (work team, virtual team, groups, and friends' network, etc...)

Both, [8] and [28] explanations focus on individual and environment. Both highlight the importance of individual participation in order to construct and acquire knowledge to learn. Their interpretation of social learning explains how social networks contribute to individuals learning within their contexts and environments. In spite of the coherence between the two authors, there are some differences. As, [8] focuses on individuals and environments to explain learning, but his concern was to explain the cognitive process in which individuals learn. While Wenger [28] discuss how individuals build their knowledge and learn within their community of practice.

\section{Social NeTworking Sites As EduCational Tool}

Social networks sites are considered as web-based services that allow individuals to build their profile and share it with others whom they have sharing connections and views. It is an internet community where people who meet, connect and share their ideas and views [21]. Social networking is a technology that promotes collective intelligence by means of social negotiation among group of individuals that are engaged in working towards a common goal or a shared practice [13]. The emergence of social network sites enable people to connect and build new relationships with whom have similar interests and preferences, it enables them to construct and 
grow their social relationships networks. These relationships could be based on friendship, professional relationships or others. There are many examples of such social network sites that attracted a lot of internet users; Twitter, Friendster, MySpace, Facebook, LinkedIn, YouTube and many others. These social networks had been used widely by many individuals for different purposes. However, a growing used for these social networks sites had been made by young individuals, whom are known as digital natives. Research reported an impressive increasing \% of using social networks sites by students and educators $[11,21]$. Students are attracted to social network sites more than traditional e-learning technologies [21]. Students who joined and participate on these sites are free to express their concerns, ask questions, communicate, and develop their own skills based on what they desire and like. A learner on social network websites are building their learning experience and knowledge by interacting with different expertise located in different places, and overcoming the time, place constrains [12]. Thus, Social networks sites are motivating students to interact communicate and motivate them to participate effectively in their learning environments.

Consequently, institutions within the education industry should integrate these social networks sites and it's different features within the learning process in more formal and designed approach to reap its benefits [21, 12]. For example, Tuan and Tu [24] highlighted improvements on Vietnamese students' performance. They found that using social networks by students helped in enhancing their grades because of the nature of social networks, which enable students to connect, interact and communicate with others.

A study done by Carroll and his colleagues [29] proved that incorporating social networks within the learning process has positive influence on students learning. They found that students of Queensland University of Australia had deeper and longer learning and had the ability to be more innovative in their research assignment because of using Wiki-spaces (http://www.wikispaces.com) to do their assignments. Furthermore, [20] conducted a study to understand how Malaysian students' use SNSs; the study was on tertiary level included more than 6000 students. Their study confirmed that students are using SNSs for different purposes as it helps them to interact with their peers in order to engage in discussion and informal learning processes. Another study by [23] focused on investigating the influence of Facebook on the learning process and her results proved that using Facebook and peer assessment in hybrid learning environment improves knowledge construction, enhances student engagement and interest and promote collaborative learning. The findings showed that students believe in the role of using social networking sites as a help in improving communication, interaction and creative learning [10]. For instance, many scholars $[22,24]$ in their researches regarding using social networks for education such as Facebook; claimed that Facebook should be considered as social place to interact and build relationships and should not be used as educational tool. In addition, it had been found that students who use these social networks sites believe that they spent a lot of time on these SNS, which may influence their academic performance [21]. However, the abovementioned studies have not shown any differences between male and female behavior in such social networking websites. Although, many studies shows differences between female and male in using the internet. Some studies found that male are interacting more than female when it comes to the online interactions [30 - 33]. 


\section{Social Networking Sites In Arab Context}

Arab social media report (2015) shows that Arab world is heavily using and embracing the new technologies of social networks. The report shows that there is exponential increase in using the social networking sites since its introduction to Arab world before one decade. Also, it shows that the mostly used social networking sites are Facebook and What Sapp. For example, In Saudi Arabia, based on Arab social media report (2015), the most used social networking sites are What's app, Facebook and Twitter. Also, it had been found that Saudi Arabia having the highest penetration regarding the social media users (Facebook 19.2\%, 2.5 LinkedIn, 2.9\% in Twitter, and the highest number of YouTube views in the world per internet user which is 90 million video views per day) (Dubai School of Government" report, 2012). Thus, we can say that the Saudi Arabia is aggressively embracing these new technologies by its citizens and incorporating its applications in different aspects of their lives. This aggressive contribution with new social networking sites trend could be explained by the high internet penetration $66 \%$ and the high demands of internet services and broadband as reported by the International Telecommunication Union (ITU) (2015).

A study done by [27] shows that an emerging domain for using social networking sites is in higher education. Their study shows a good level of acceptance and using of social networking sites within Saudi universities. The universities which had been studied are using social networking sites particularly Twitter, Facebook, YouTube and LinkedIn within the learning formal process. However, they recommend that using social networking within higher education needs more research in order to understand the usage of SNS and understand the behavior of students and educators. Another study was focusing on studying the acceptance of using SNS by using TAM model such as [2] \& [3], the first part of this study on Social Media usage in Saudi Arabia is mainly exploratory in nature aiming at investigating the attitude of the average Saudi towards the use of Social Media. In spite the wide use of social networking sites by Saudi, there are studies reporting a low percentage of using social networking sites for educational purposes $[7,19]$. Thus, more studies needed to be done in order to understand students' perceptions about using SNSs as educational tool.

In [1] studied the Jordanians youth perspective regarding using the SNSs in the learning process. Their study was focusing on the studying the pros and cons of Facebook. They found that Jordanians students are aware of the advantages and disadvantages of using Facebook for learning. Another study in Jordan was done by [6]. They found that SNSs had positive effect on Jordanian youths on the individual level and the participants believe that it has no negative effect on their learning progress. However, both studies recommend further studies to explorer this issue and including other SNS. In addition, we could not find any studies highlighted the gender differences in using social networking websites at the developing countries level and more specifically on the Middle East Countries.

\section{RESEARCH METHOdOLOGY}

This research intends to identify which social networking website is used by students and discover the students' perceptions of using social networking websites within their learning process. In order to realize this goal, the researcher developed a questionnaire into three parts; the first part was intend to collect demographic data, the second part was to know the most used social networking website for different purposes by students, and finally, the third part was to highlight the advantages and disadvantages of using SNSs from students perspective using 5likert scale. 
The questionnaire had been developed using monkey survey and the link of the questionnaire had been posted on Black Board at Al Imam Mohammad Ibn Saud University and University of Jordan. Also, the link of the survey had been distributed via social media such as (Twitter, LinkedIn and Whatsapp) in order to reach larger sample. The questionnaire was available for 3 months for information system department students. 178 students had been answering the questionnaire, 124 responses are completed and used for further analysis. The collected data had been analyzed to obtain more information.

\section{DAta AnAlysis AND ReSUlts}

Although the survey had been distributed via social media sites in order to increase the participation, the researcher only received 178 responses, 124 responses were completed

\subsection{Demographic Data Analysis}

A total of 124 students from University of Jordan and Imam Muhammad Ibn Saud Islamic University from Business Information system and information system departments participated in the survey out of which $85 \%$ (106) were females, whereas $15 \%$ (18) were males as shown in Table (1) and Figure (1);

Table 1: Gender Distribution

\begin{tabular}{|l|l|l|l|l|l|}
\hline \multicolumn{2}{|l|}{ Gender } & Frequency & Percent & Valid Percent & $\begin{array}{l}\text { Cumulative } \\
\text { Percent }\end{array}$ \\
\hline \multirow{3}{*}{ Valid } & & 1 & .8 & .8 & .8 \\
\cline { 2 - 6 } & Female & 106 & 84.8 & 84.8 & 85.6 \\
\cline { 2 - 6 } & Male & 18 & 14.4 & 14.4 & 100.0 \\
\cline { 2 - 6 } & Total & 125 & 100.0 & 100.0 & \\
\hline
\end{tabular}

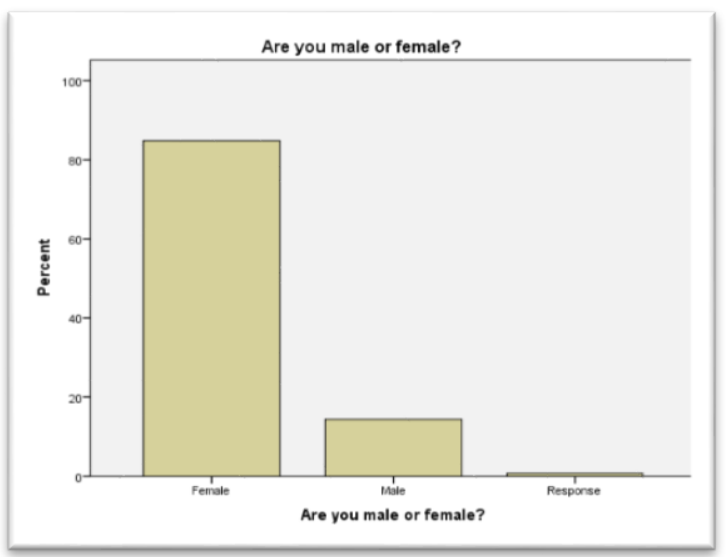

Figure 1: Gender Distribution

In addition, table (2) shows that out of 125 respondents, 64 respondents are between ages 18-20, 57 are between ages of 21-29, 2 are between the interval of 30-39 and only 1 respondent lies between the age group of 40-49. Thus, $51 \%$ aging between $18-20$, whereas rest of the $49 \%$ were above $20 \%$. 
International Journal of Managing Information Technology (IJMIT) Vol.9, No.2, May 2017

Table 2: Age Distribution

\begin{tabular}{|l|l|l|l|l|l|}
\hline \multicolumn{2}{|l|}{ Age } \\
\hline \multicolumn{2}{|c|}{} & Frequency & Percent & Valid Percent & $\begin{array}{l}\text { Cumulative } \\
\text { Percent }\end{array}$ \\
\hline \multirow{6}{*}{ Valid } & & 1 & .8 & .8 & .8 \\
\cline { 2 - 6 } & $18-20$ & 64 & 51.2 & 51.2 & 52.0 \\
\cline { 2 - 6 } & $21-29$ & 57 & 45.6 & 45.6 & 97.6 \\
\cline { 2 - 6 } & $30-39$ & 2 & 1.6 & 1.6 & 99.2 \\
\cline { 2 - 6 } & $40-49$ & 1 & .8 & .8 & 100.0 \\
\cline { 2 - 6 } & Total & 125 & 100.0 & 100.0 & \\
\hline
\end{tabular}

Most of them belonged to (71) 57\% Al-Imam Muhammad Ibn Saud Islamic University and the rest of them (53) $43 \%$ were belonging to University of Jordan. $82 \%$ of the respondents were enrolled as undergraduate students at college or university.

Table 3 Nationality Distribution

\begin{tabular}{|l|l|l|l|l|l|}
\hline \multicolumn{2}{|l|}{ Nationality } & Frequency & Percent & $\begin{array}{l}\text { Valid } \\
\text { Percent }\end{array}$ & $\begin{array}{l}\text { Cumulative } \\
\text { Percent }\end{array}$ \\
\hline \multirow{3}{*}{ Valid } & & 31 & 24.8 & 24.8 & 24.8 \\
\cline { 2 - 6 } & Jordanian & 54 & 43.2 & 43.2 & 68.0 \\
\cline { 2 - 6 } & Palestinian & 2 & 1.6 & 1.6 & 69.6 \\
\cline { 2 - 6 } & Saudian & 37 & 29.6 & 29.6 & 99.2 \\
\cline { 2 - 6 } & Yemeni & 1 & .8 & .8 & 100.0 \\
\cline { 2 - 6 } & Total & 125 & 100.0 & 100.0 & \\
\hline
\end{tabular}

The frequency table drawn above shows that most of the respondents are of Jordanian Nationality i.e. 54, 37 are Saudi and very few are from Yemen and Palestine. All the students shared different response on a question on average use of social media; the response ranged from 1-23 hours per day. The objective to use these sites was even more diverse; generally, students use it for various reasons related to learning and enjoyment. Following analysis is based upon sharing of top three results in each category, which are highly significant.

\subsection{The Most Used Snss For Different Activities}

On a question about the most used networking site, What Sapp with 8.47 out of 10 points was found on the top, Facebook was at the second place with 7.06 out of 10 points while YouTube 6.82 out of 10 points is used as the third common source.

For finding friends, Face book with 8.58 out of 10 points was found on the top, Twitter was at the second place with 7.98 out of 10 points while What Sapp with 7.51 out of 10 points is used as the third common source. What's app was considered to be the most valuable social application for sending and receiving messages having the score 9.33 out of 10, whereas Face book with 8.09 and twitter with 7.95 were the next in line to be helpful in this regard. What's app was consideredthe most valuable social application for chatting with friends having the score 9.26 out of 10, whereas Face book with 8.12 and twitter with 7.96 were the next in line to be helpful in this regard. For playing games, Face book with 6.56 out of 10 points was found on the top, 
Twitter was at the second place with 8.20 out of 10 points while Google+ with 7.79 out of 10 points is used as the third common source.

For file sharing, Face book with 8.71 out of 10 points was found on the top, Twitter was at the second place with 8.08 out of 10 points while What'sapp with 7.89 out of 10 points is used as the third common source. Facebook was considered to be the most valuable website for academic communication with friends having the score 8.73 out of 10, whereas What Sapp with 8.17 and twitter with 7.89 were the next in line to be helpful in this regard. The same with reference with instructors were Face book, Twitter and What Sapp with respective score of 8.74, 8.16, and 7.51. Face book was on top for engaging in academic discussion, whereas twitter and Google+ are the next with scores 8.78, 8.21 and 7.54. Same for learning concept, were Face book, Twitter and Google, with the scores $8.30,7.88$ and 7.26 respectively. Accordingly, study shows that Face book got the highest average score; 8.47 out of 10 , which is around $85 \%$ of the total score, whereas Twitter was at the second highest average; 7.89 out of 10 , which is around $79 \%$ of the total score. While analysis shows the third highest average was found with Google+ which secured 7.32 average score with a percentage of $73 \%$. This analysis shows how we can compare more than 2 constants against several variables; in this case 10. That is why the statisticians not only find the top tendencies in comparison, but also the realistic situation and status of each constant. Following table presents statistical analysis of each constant against ten variables. Table 4Summary table of most used SNSs

Table 4: Summary table of most used SNSs

\begin{tabular}{|l|l|l|l|l|l|l|l|l|l|l|}
\hline & Twitter & FaceBook & LinkedIn & Google+ & $\begin{array}{l}\text { What's } \\
\text { app }\end{array}$ & Instagram & Pinterest & Skype & Badoo & YouTube \\
\hline 1 & 6.54 & 7.06 & 4.51 & 5.03 & 8.47 & 6.79 & 3.19 & 4.67 & 1.92 & 6.82 \\
\hline 2 & 7.98 & 8.58 & 5.61 & 5.36 & 7.51 & 6.97 & 3.6 & 4.37 & 1.91 & 3.12 \\
\hline 3 & 7.95 & 8.09 & 5.94 & 9.33 & 5.18 & 5.85 & 3.62 & 4.98 & 2.08 & 1.97 \\
\hline 4 & 7.96 & 8.12 & 5.91 & 9.26 & 4.81 & 6.27 & 3.62 & 4.91 & 2.14 & 2 \\
\hline 5 & 8.2 & 9.56 & 7.79 & 6.63 & 5.44 & 5.16 & 4.01 & 3.46 & 2.47 & 2.29 \\
\hline 6 & 8.08 & 8.71 & 7.27 & 7.89 & 5.27 & 5.71 & 3.64 & 3.59 & 1.85 & 3 \\
\hline 7 & 7.89 & 8.73 & 6.71 & 8.17 & 5.76 & 4.92 & 3.59 & 4.43 & 1.93 & 2.87 \\
\hline 8 & 8.16 & 8.74 & 7.41 & 7.51 & 5.89 & 4.84 & 3.73 & 4.34 & 2.03 & 2.35 \\
\hline 9 & 8.21 & 8.78 & 7.54 & 7.24 & 5.57 & 4.83 & 3.56 & 4.35 & 1.99 & 2.94 \\
\hline 10 & 7.88 & 8.3 & 7.26 & 6.8 & 5.54 & 4.43 & 3.41 & 3.58 & 1.95 & 5.86 \\
\hline & & & & & & & & & & \\
\hline Total & 78.85 & 84.67 & 65.95 & 73.22 & 59.44 & 55.77 & 35.97 & 42.68 & 20.27 & 33.22 \\
\hline & 7.89 & 8.47 & 6.60 & 7.32 & 5.94 & 5.58 & 3.60 & 4.27 & 2.03 & 3.32 \\
\hline$\%$ & 78.85 & 84.67 & 65.95 & 73.22 & 59.44 & 55.77 & 35.97 & 42.68 & 20.27 & 33.22 \\
\hline
\end{tabular}

Furthermore, ANOVA table drawn shows that variable Facebook and LinkedIn are significant of all as their p-values are less than Alpha i.e. less than alpha. Thus, we can say that these are two social networking sites that are mostly used by the respondents. Whereas the rest of the others are insignificant as their p-values are greater than alpha. 
International Journal of Managing Information Technology (IJMIT) Vol.9, No.2, May 2017

Table 5: One way ANOVA on Rank question regarding Social Networking

\begin{tabular}{|c|c|c|c|c|c|c|}
\hline \multicolumn{7}{|l|}{ ANOVA } \\
\hline & & $\begin{array}{l}\text { Sum of } \\
\text { Squanes }\end{array}$ & df & $\begin{array}{l}\text { Mean } \\
\text { Squars }\end{array}$ & $\mathrm{F}$ & Sig. \\
\hline \multirow[t]{3}{*}{ Twider } & $\begin{array}{l}\text { Beboreen } \\
\text { Giroups }\end{array}$ & 20.047 & 3 & 9.016 & 3.469 & .020 \\
\hline & Within Grouss: & 220.908 & 85 & 2.599 & & \\
\hline & Total & 247.955 & 88 & & & \\
\hline \multirow[t]{3}{*}{ Faxbook } & $\begin{array}{l}\text { Beboreen } \\
\text { Groups } \\
\end{array}$ & 88709 & 3 & 29.570 & 7596 & .000 \\
\hline & Within Groups: & 330.908 & 85 & 3.893 & & \\
\hline & Total & 419.618 & 88 & & & \\
\hline \multirow[t]{3}{*}{ Linkedln } & $\begin{array}{l}\text { Beboreen } \\
\text { Groups }\end{array}$ & 39.190 & 3 & 13.063 & 3.172 & .028 \\
\hline & Within Groups: & 350.046 & 85 & 4.118 & & \\
\hline & Total & 389.236 & 88 & & & \\
\hline \multirow[t]{3}{*}{$\begin{array}{l}\text { Coogke } \\
\text { plus }\end{array}$} & $\begin{array}{l}\text { Betbreen } \\
\text { Groups }\end{array}$ & 2503 & 3 & 834 & 351 & .788 \\
\hline & Within Groups: & 201992 & 85 & 2.376 & & \\
\hline & Total & 204.494 & 88 & & & \\
\hline \multirow[t]{3}{*}{ Whatsayp } & $\begin{array}{l}\text { Bebween } \\
\text { Groums }\end{array}$ & 10.045 & 3 & 3.348 & 504 & .680 \\
\hline & Within Groups: & 564.203 & 85 & 6.638 & & \\
\hline & Total & 574.247 & 88 & & & \\
\hline \multirow[t]{3}{*}{ Instapram } & $\begin{array}{l}\text { Bebween } \\
\text { Giroups }\end{array}$ & 16.311 & 3 & 5.437 & 1.289 & .284 \\
\hline & Within Grouss & $\begin{array}{l}358.588 \\
5\end{array}$ & 85 & 4.219 & & \\
\hline & Total & 374.899 & 88 & & & \\
\hline \multirow[t]{3}{*}{ Prnterest } & $\begin{array}{l}\text { Beboreen } \\
\text { Groups }\end{array}$ & 530 & 3 & .177 & .091 & .965 \\
\hline & Within Groups: & 164.908 & 85 & 1.940 & & \\
\hline & Total & 165.438 & 88 & & & \\
\hline \multirow[t]{3}{*}{ Skype } & $\begin{array}{l}\text { Bebween } \\
\text { Giroups }\end{array}$ & 2302 & 3 & .767 & 211 & .888 \\
\hline & Within Groums & 308.462 & 85 & 3.629 & & \\
\hline & Total & 310764 & 88 & & & \\
\hline \multirow[t]{3}{*}{ Badoo } & $\begin{array}{l}\text { Beboreen } \\
\text { Groups }\end{array}$ & 098 & 3 & .033 & .043 & .988 \\
\hline & Within Grous: & 6.183 & 85 & .767 & & \\
\hline & Total & 6.281 & 88 & & & \\
\hline \multirow[t]{3}{*}{ YouTithe } & $\begin{array}{l}\text { Beboreen } \\
\text { Groups } \\
\end{array}$ & 32595 & 3 & 10.865 & 1.752 & .162 \\
\hline & Within Groums & 527.046 & 85 & 6.201 & & \\
\hline & Total & 559.640 & 88 & & & \\
\hline \multirow[t]{3}{*}{ gender } & $\begin{array}{l}\text { Bebureen } \\
\text { Groups }\end{array}$ & 909 & 3 & .303 & 2512 & .062 \\
\hline & Within Groups: & 14.478 & 120 & .121 & & \\
\hline & Total & 15.387 & 123 & & & \\
\hline
\end{tabular}

We run another test, to see if there is a relationship between the gender, nationality and the using of SNs websites. The tables below present these associations.

Table 6: Case-Processing Summary

\begin{tabular}{|l|r|r|r|r|r|r|}
\hline \multicolumn{2}{|c|}{ Case Processing Summary } \\
\hline & \multicolumn{3}{|c|}{ Cases } \\
\cline { 2 - 8 } & \multicolumn{2}{|c|}{ Valid } & \multicolumn{2}{c|}{ Missing } & \multicolumn{2}{c|}{ Total } \\
\cline { 2 - 8 } & $\mathrm{N}$ & Percent & $\mathrm{N}$ & Percent & $\mathrm{N}$ & Percent \\
\hline $\begin{array}{l}\text { Are you male or female? * } \\
\text { Which social networking } \\
\text { websites do you use most } \\
\text { often? Please note, } \\
\text { the most used network is } \\
\text { ranked as 1 and theleast } \\
\text { used one is ranked as 10 }\end{array}$ & 95 & $76.0 \%$ & 30 & $24.0 \%$ & 125 & $100.0 \%$ \\
\hline $\begin{array}{l}\text { In what country do you } \\
\text { currently reside? * Which } \\
\text { social networking websites } \\
\text { do you use most often? } \\
\text { Please note, the most used } \\
\text { network is ranked as 1 and } \\
\text { the least used one is } \\
\text { ranked as 10 }\end{array}$ & 95 & $76.0 \%$ & 30 & $24.0 \%$ & & \\
\hline
\end{tabular}


Table 7: Crosstab analysis between Gender and the most used Social networking websites

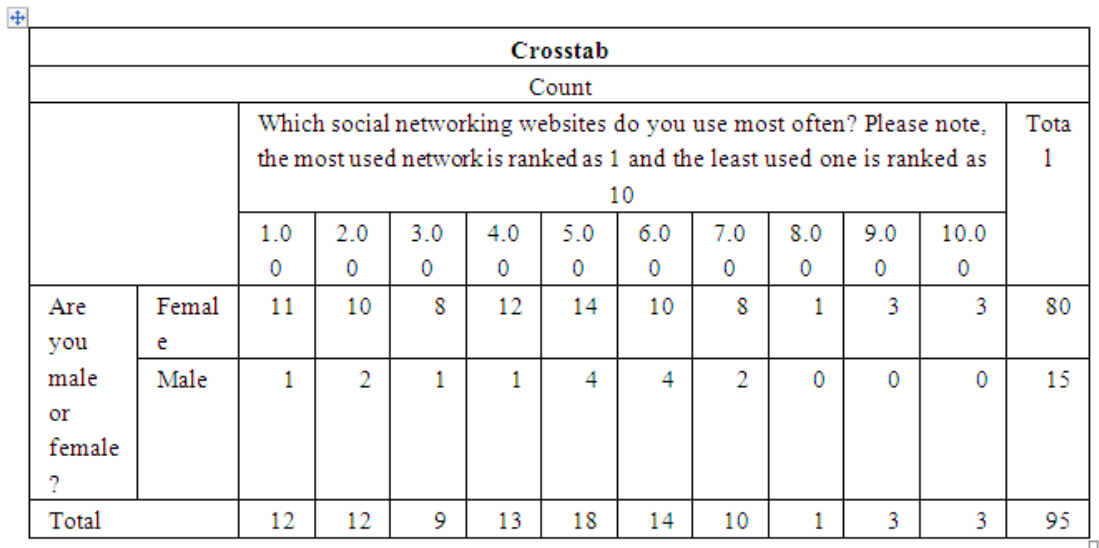

Table 8: Chi-Square Tests

\begin{tabular}{|l|r|r|r|}
\hline \multicolumn{5}{|c|}{ Chi-Square Tests } \\
\hline & \multicolumn{1}{|c|}{ Value } & df & $\begin{array}{c}\text { Asymptotic Significance } \\
\text { (2-sided) }\end{array}$ \\
\hline Pearson Chi-Square & $5.024:$ & 9 & .832 \\
\hline Likelihood Ratio & 6.014 & 9 & .738 \\
\hline N of Valid Cases & 95 & & \\
\hline a. 13 cells (65.0\%) have expected count less than 5. The minimum expected count is .16. \\
\hline
\end{tabular}

From the above drawn table we can say that p-value is greater than alpha i.e. $\mathbf{0 . 8 3 2}>\mathbf{0 . 0 5}$. Thus, we conclude that there's no association between the nationality, gender and specific use of SNS's.

\subsection{DISADVANTAGES AND ADVANTAGES OF USING SNSS FROM STUDENT' PERCEPTIONS'}

For the third part, only highest figure is shared here. $42 \%$ agreed that these sites have negative impact on studies and cause distraction, $38.46 \%$ students agreed that these services require money and cause time wastage, which may affect academic life adversely, while $35 \%$ agreed that it is problematic. $32 \%$ found it hard to concentrate on studies because of games, and $29.87 \%$ agreed that their grades were dropped, but $33.77 \%$ responded that there is no decline in the grades. Also $30.77 \%$ disagreed that it was useless for education; while 50\% agreed that SNS is useful for higher educational institutions for communication and 43.84 considered this to be useful for group discussion.

44.59 strongly agreed that social media sites can help to get the announcements and lectures from the faculty, while 33.78 agreed the same. $38 \%$ and $41 \%$ strongly agreed and agreed respectively that SNSs are helpful for discussion on assignments with friends. $30 \%$ and $46.58 \%$ strongly agree and agree respectively that it improves interaction between classmates and lecturers, while $33 \%$ and 38.67 agreed that SNSs can facilitate academic activities and coordination with friends. $30.14 \%$ and $46.58 \%$ say that it is really helpful for learning new concepts related to education. $39 \%$ respondents agreed and $33.78 \%$ of them strongly agreed that through SNSs they could arrange group discussions with the students of other institutes as well.

As a result of a general analysis, it can be concluded that there is a consensus that SNS can be advantageous if utilized in a right direction to facilitate education; however, it is also clear that there are some disadvantages as well in terms of time management issues which are over and above these advantages, which could possibly take place. This contrast occurred in the third part 
of the survey when they were asked about the usefulness; although all of those use some or all of these services, but agree that these have more demerits. Those who considered these as helpful, also shared some concerns, which leads towards a conclusion that the use of SNS in a controlled manner, focusing to avoid its negative impacts.

Table 2: Students Responses for Advantages and Disadvantages of using SNSs

\begin{tabular}{|l|c|c|c|c|c|}
\hline Variables & $\begin{array}{l}\text { Strongy } \\
\text { agree }\end{array}$ & Agree & Neither & disagree & $\begin{array}{c}\text { Strongy } \\
\text { disagree }\end{array}$ \\
\hline Negative impact of SNS & 16.67 & 42.31 & 24.64 & 15.38 & 0 \\
\hline Money and time wastage & 10.26 & 38.46 & 20.51 & 25.64 & 5.13 \\
\hline SNS as problematic issue & 14.29 & 35.06 & 27.27 & 23.38 & 0 \\
\hline Bad impact of games & 18.92 & 32.43 & 22.97 & 14.86 & 10.81 \\
\hline Drop in grades & 6.49 & 29.87 & 33.77 & 18.18 & 11.69 \\
\hline SNS are useless for education & 10.26 & 19.23 & 16.67 & 30.77 & 23.08 \\
\hline Helpful for communication & 25.33 & 50.67 & 14.67 & 8 & 1.33 \\
\hline For group discussion & 34.25 & 43.84 & 13.7 & 6.85 & 1.37 \\
\hline For announcements and lectures & 44.59 & 33.78 & 17.57 & 4.05 & 0 \\
\hline $\begin{array}{l}\text { For assignment discussion with } \\
\text { friends }\end{array}$ & 38.36 & 41.1 & 12.33 & 8.22 & 0 \\
\hline For improved interactions & 30.14 & 46.58 & 13.7 & 6.85 & 2.74 \\
\hline For academic coordination & 33.33 & 36.67 & 16 & 10.67 & 1.33 \\
\hline for new concepts & 30.14 & 46.58 & 12.33 & 9.59 & 1.37 \\
\hline $\begin{array}{l}\text { FGD from those coming from other } \\
\text { University }\end{array}$ & 33.78 & 39.19 & 17.57 & 8.11 & 1.35 \\
\hline
\end{tabular}

\subsection{RESULTS COMPARISON BASED ON COUNTRY-WISE}

When comparing the results on country wise, 53 respondents' $43 \%$ of total 124 ; were from Jordan by Nationality. Out of those, 50 students' $94 \%$ of the total 53 considered Face Book as their number one SNS site to be used for networking. Whereas; the next priority was What's app, as declared by $80 \%$ of the Jordanian students. Other networks were not at the priority at all, while Instagram and You Tube were totally rejected by the majority as the most used network.

71 students of Saudi Nationality; 57\% of total 124 participated in the survey; showing huge inclination towards What's app. On analyzing and comparing the responses from the Saudi students it was found that What's app was the most commonly used network by 66 respondents; 92\% of total 71 students from Saudi Arabia. For YouTube, 16 students (22.5\%) agreed to be their first network, whereas, for twitter, 11 students $(15 \%)$ agreed as the top priority for social networking. The rest of the networks were generally rejected as their top priority.Following tables $(3,4)$ present an overview on the country wise comparison 
International Journal of Managing Information Technology (IJMIT) Vol.9, No.2, May 2017

Table 3: Responses from Jordanian Students

\begin{tabular}{|r|l|l|l|}
\hline Sr. No & Social Network Website & Top priority & Low or medium prority \\
\hline 1. & Twitter & 6 & 47 \\
\hline 2. & Facebok & 50 & 3 \\
\hline 3. & LinkedIn & 4 & 49 \\
\hline 4. & Google + & 4 & 49 \\
\hline 5. & What's app & 43 & 10 \\
\hline 6. & Instagram & 0 & 53 \\
\hline 7. & Pineterest & 0 & 53 \\
\hline 8. & Skype & 0 & 53 \\
\hline 9. & Badoo & 0 & 53 \\
\hline 10. & You Tube & 0 & 53 \\
\hline
\end{tabular}

Table 4: Responses from Saudi Students

\begin{tabular}{|l|l|l|l|}
\hline Sr. No & Social Network Website & Top priority & Low or medium priority \\
\hline & Twitter & 11 & 60 \\
\hline & Facebook & 3 & 68 \\
\hline & LinkedIn & 1 & 70 \\
\hline & Google + & 4 & 67 \\
\hline & What's app & 66 & 9 \\
\hline & Instagram & 0 & 71 \\
\hline & Pineterest & 0 & 71 \\
\hline & Skype & 0 & 71 \\
\hline & Badoo & 0 & 71 \\
\hline & You Tube & 16 & 55 \\
\hline
\end{tabular}

The data shows clear contrast when a country wise analysis was conducted. All the entries showing 0 in the table should be interpreted as none of the respondents declared the particular network as his mostly used site. Whereas showing a higher number of respondents in low priority refers to the students who do not use this network.

As of second part of the questionnaire, majority of the students (around 80\%) from Jordan agreed that it has more disadvantages and the demerits than advantages. In case of Saudi students, there was a mixed response, (around 40\%) disagreed for its negative impacts, and around 60\% were convinced on its advantages for group work. Nevertheless, there was also a majority of the students who emphasized that SNSs are more the source of distraction and wastage of money and time regardless of their response in the favor or against the SNS sources 


\section{Conclusion}

Above data clearly shows clear tendencies of the students to use SNSs as an academic resource. In the mid part though, a higher percentage of students have mentioned these as a means of time wastage and distraction although they have also admitted there addiction to these sites. Face book, Twitter and Google+ are clearly visible as students' top admiration in most of the cases, whereas What Sapp also appears for some positive uses by the students. This shows that Social networking is an integral part of their daily life.

Furthermore, the results show that students are using social networking websites by spending a lot of time on them; most of them claim they are using social networking sites after every 30 minutes. Some of them agreed about the advantages and the disadvantages of using the social networks. This shows the awareness level of students about the bad and good side of using these SNSs. However, most of them agree that using SNSs is considered as time wasting. This is due to lack of skills in time management, which can be improved and enhanced by providing workshops about the good practices for time management. It is required from instructors to rule and regulate the usage of SNSs with in the educational process. However, interesting results appear when we compared the results of usage of SNSs country-wise. Although the sample is not evenly distributed, we noticed that, Jordanian University prefer to use Facebook for communication and learning, which is coherent with previous research [16]. This is different from what had been reported by Saudi students who prefer what's app as tool for communication and discussion. Some students prefer to give the information in condense and textual approach with no destruction with other features that appears as in Facebook. Some students have the ability to do multitask, while they are browsing certain social networking website and thus make their learning process more enjoyable. However, the analysis shows that there is no association between gender and using specific social networking websites at the academic level. As for our knowledge, no other studies showed the gender role on using social networking as educational tool in the Middle East countries.

This study helps us in understanding the importance of social networking website for learning and academic use by students as these sites help instructors and instructional designers to incorporate such features in their learning management systems and educational tool designs [15]. In addition, instructors came to know how to integrate these tools within their teaching process.

Future research should focus the use of social networking websites within the educational process and should explain the measures to integrate these technologies within the learning process. More studiesshould be made to fill the gap and enrich the academic filed regarding social networking websites in developing countries.

\section{REFERENCES}

[1] Abu-Shanab, Emad A., Al-Tarawneh, Heyam A.(2013).How Jordanian Youth Perceive Social Networks Influence?. Computer Science and Information Technology 1(2): 159-164, 2013. DOI: 10.13189/csit.2013.010213.

[2] Al-Ghaith, W. (2016). Applying and extending the Technology Acceptance Model to understand Social Networking Sites (SNS) Usage: Toward proposing a comprehensive model. In Proceedings of the The 3rd Multidisciplinary International Social Networks Conference on SocialInformatics 2016, Data Science 2016 (MISNC, SI, DS 2016). ACM, New York, NY, USA, Article 20, 8 pages. DOI: https://doi.org/10.1145/2955129.2955149

[3] Al-Ghaith, W. (2015). Understanding Social Network Usage: Impact of Co-Presence, Intimacy, and Immediacy. (IJACSA) International Journal of Advanced Computer Science and Applications, 6(8), 99-111 
[4] AlJeraisy, M.N., Mohammad, H., Fayyoumi, A., \&AlRashideh, W. (2015). Web 2.0 in education: The impact of discussion board on student performance and satisfaction. The Turkish Online Journal of Educational Technology, 14(2), 247-260.

[5] Antonacopoulou, E.P. and Chiva, R. (2007) The social complexity of organizational learning: dynamics of learning and organising. Management Learning, 38, pp. 277-296

[6] Al-Oqily, I., Alkhatib, G., Al-Khasawneh, A. \&Alian, M. (2013). Social networks impact: The case ofJordanian youth. International Journal of Continuing Engineering Education and Lifelong Learning,23(1), 100-114.

[7] Althemairy, A. (2013, February 22). Million users of social networks in Saudi Arabia without the benefit of learning. Alegtisadiah News. Retrieved July 4, 2014, from http://www.aleqt.com/2013/02/22/article_733633.html

[8] Bandura, A. (1977). Self-efficacy: Toward a unifying theory of behavioral change. Psychological Review, 84(2), 191-215

[9] Bennett, S., Bishop, A., Dalgarno, B., Waycott, J. \& Kennedy, G. (2012). Implementing Web 2.0 technologies in higher education: A collective case study. Computers \& Education, 59(2),524-534.

[10] Buzzetto-More N. A. (2012) Social networking in undergraduate education. Interdisciplinary Journal of Information, Knowledge, and Management 7, 63-90

[11] Dabbagh, N., \&Kitsantas, A., Personal Learning Environments, social media, and self-regulated learning: A natural formula for connecting formal and informal learning, Internet and Higher Education (2011), doi:10.1016/j.iheduc.2011.06.002

[12] Claros, I., Cobos, R., \&Collazos,C. A .(2016). "An Approach Based on Social Network Analysis Applied to a Collaborative Learning Experience," in IEEE Transactions on Learning Technologies, vol. 9, no. 2, pp. 190-195, April-June 1 2016. doi: 10.1109/TLT.2015.2453979

[13] Gunawardena, C. N., Hermans, M. B., Sanchez, D., Richmond, C., Bohley, M., \& Tuttle, R. (2009). A theoretical framework for building online communities of practice with social networking tools. Educational Media International, 46 (1), 3-16.

[14] Greenhow, C. (2011). Online social networks and learning. On the Horizon, 19(1), 4-12.

[15] Lahiri, M., \& Moseley, J. L. (2015). Learning by Going Social: Do We Really Learn from Social Media?. International Journal of Learning, Teaching and Educational Research, 11(2).

[16] Maqableh, M.M., Rajab, L., Quteshat, W., Masa'deh, R.M.T., Khatib, T. and Karajeh, H. (2015). TheImpact of Social Media Networks Websites Usage on Students' Academic Performance. Communications and Network, 7, 159-171. http://dx.doi.org/10.4236/cn.2015.74015

[17] Manca, S. and Ranieri, M. (2013), Is it a tool suitable for learning? A critical review of the literature on Facebook as a technology-enhanced learning environment. Journal of Computer Assisted Learning, 29: 487-504. doi: 10.1111/jcal.12007

[18] http://www.mcit.gov.sa/En/aboutmcit/sectordevelopment/pages/sectorindices.aspx

[19] Kutbi, Alaa Ibraheem, "How Undergraduate Female Students in the Kingdom of Saudi Arabia Perceive Social Media as a Learning Tool: An Exploratory Study" (2015). Electronic Theses and Dissertations. Paper 5290.

[20] Hamat, A., Embi, M., \& Hassan, H. (2012). The Use of Social Networking Sites among Malaysian University Students. International Education Studies, Vol.5 (3), pp.56-66.

[21] Helou, A. M., \& Rahim, N. Z. A. (2014). The Influence Of Social Networking Sites On Students'academic Performance In Malaysia. International Journal Of Electronic Commerce, 5(2).

[22] Madge, C. , Meek, J. , Wellens, J., Hooley, T. (2009). Facebook, social integration and informal learning at university: It is more for socializing and talking to friends about work than for actually doing work Learning, Media and Technology, 34 (2) (2009), pp. 141-155 http://dx.doi.org/10.1080/17439880902923606

[23] Shih, R.-C. (2011). Can Web 2.0 technology assist college students in learning English writing? Integrating Facebook and peer assessment with blended learning. In J. Waycott\& J. Sheard (Eds), Assessing stu-dents' Web 2.0 activities in higher education. Australasian Journal of Educational Technology, 27(Special issue, 5), 829-845. Retrieved from http://www.ascilite.org.au/ajet/ajet27/shih.html

[24] Selwyn, N. (2009). Faceworking: exploring students' education-related use of Facebook. Learning, Media and Technology, 34(2), 157-174.

[25] Tuan, N. \&Tu, N (2013). The Impact of Online Social Networking on Students' Study. VNU Journal of Education Research, Vol. 29(1), 2013, pp. 1-13.

[26] Zhu, C. (2012). Student satisfaction, performance, and knowledge construction in online collaborative learning. Journal of Educational Technology \& Society, 15(1), 127-136. 
[27] Al-Khalifa, H. S., \& Garcia, R. A. (2013). The State of Social Media in Saudi Arabia's Higher Education. International Journal of Technology and Educational Marketing (IJTEM), 3(1), 65-76. doi:10.4018/ijtem.2013010105

[28] Wenger, E. (1998), Communities of Practice - Learning, Meaning and Identity, Cambridge University Press, Cambridge

[29] Carroll, J., Diaz, A., Niland, C., Meiklejohn, J., \& Adkins, B. A. (2012). „Show Me Your Wiki and I'll Show you Mine ${ }^{e e}$ : Using Online Interactive Media to Improve Academic Writing and Research in a Public Health Under-Graduate Cohort. In Martellini, Lorenzo (Ed.) The Future of Education Conference Proceedings 2012, SimonelliEditore, Florence, Italy, pp. 43-48.

[30] Chan and Fang, (2007) K. Chan, W. Fang. Use of the internet and traditional media among young peopleYoung Consumers: Insight and Ideas for Responsible Marketers, 8 (4) (2007), pp. 244-25

[31] Li and Kirkup, (2007)N. Li, G. Kirkup, Gender and cultural differences in internet use: A study of China and the UKComputers \& Education, 48 (2) (2007), pp. 301-307 http://dx.doi.org/10.1016/j.compedu.2005.01.007

[32] Wasserman and Richmond-Abbott, 2005, I.M. Wasserman, M. Richmond-Abbott, Gender and the internet: Causes of variation in access, level, and scope of use. Social Science Quarterly, 86 (1) (2005), pp. 252-270 http://dx.doi.org/10.1111/j.0038-4941.2005.00301.x

[33] Ang, Chin-Siang (2017), Internet habit strength and online communication: Exploring gender differences, Computers in Human Behavior, 66 (2017), SN 0747-5632. DOI https://doi.org/10.1016/j.chb.2016.09.028TY 